\title{
“课堂进企业”人才培养模式改革探索 ---基于老年服务与管理专业
}

\author{
刘小玲 \\ 泉州华光职业学院 \\ DOI:10.32629/mef.v3i6.1658
}

\begin{abstract}
[摘 要] 随着我国老年人口的不断增多, 老年服务与管理专业人才成为社会服务的紧缺人才, 如何培 养符合养老企业岗位需求的、高契合度的管理人才是高职院校相关专业的重要使命。我校通过试行老 年服务与管理专业 “课堂进企业” 人才培养模式改革方案, 探索高契合度的优质老年服务与管理人才 培养途径, 取得了一定成效。
\end{abstract}

[关键词] 课堂; 企业; 培养模式; 探索

中图分类号: G642.421 文献标识码: A

Exploration on the Reform of Talent Training Model of "Class into Enterprise" -Based on Senior Service and Management Major Xiaoling Liu

Quanzhou Huaguang Institute

\begin{abstract}
[Abstract] With the continuous increase of the elderly population in my country, senior service and management professionals have become a shortage of social services. How to cultivate high-fit management talents that meet the needs of senior care enterprises is an important mission of related majors in higher vocational colleges. Through the reform plan of "Class into Enterprise" talent training model for senior service and management majors, our school explored high-quality senior service and management talent training methods with high compatibility, and achieved certain results.
\end{abstract}

[Key words] class; enterprise; training model; exploration

泉州华光职业学院是福建省泉州市 唯一一所设有老年服务与管理专业的高 职院校, 为了培养符合企业岗位需求的、 高契合度的管理人才, 泉州华光职业学 院健康管理学院于2019年实施了老年服 务与管理专业 “课堂进企业” 人才培养 模式改革方案, 经过方案试运行, 无论 是学校、学生还是企业都有所收获。

\section{1 改革方案简介}

“课堂进企业” 人才培养模式即不 同于定单制、现代学徒制, 亦不同于二 元制而独具特色。这是一种将老年服务 与管理专业学生分成三个阶段进行培养 的模式。

第一阶段: 前两学年, 即第1-4学期, 老年服务与管理专业同年级的学生均在
学校内完成教学计划内所有公共课程、 基础课程及部分专业课程的学习任务。

第二阶段: 第5学期, 对同年级的学 生进行分流, 自主选择参加试点班学习 的学生进入合作企业完成专业技能课程 的学习, 学习地点在企业, 授课人员为 企业技术人员, 这部分学生将在企业边 学习边进行跟岗实习, 吃、住、学习、 生活均在企业。不参加试点班学习的学 生则按原培养方案继续留在学校完成与 试点班相同课程、相同学时的学习, 无 跟岗实习活动。

第三阶段: 第6学期, 所有课程结束, 试点班的学生与在学校学习的学生一 样, 均可自由选择顶岗实习单位。

“课堂进企业” 人才培养模式的创
新点在于把课堂部分移至企业, 学生直 接在企业完成部分专业技能课程的学 习, 由企业专业技术人员传授专业技能 知识, 同时进行跟岗实践, 真正融教、 学、做于一体, 从而达到 “以需求为导 向” 的人才培养目标。学生在企业里边 学习边实践, 能够真实地接触到服务对 象, 能够更加直观地理解和掌握所学的 知识, 并在实际锻炼中进一步提高技能、 树立正确的职业价值观。

\section{2 改革方案实施}

为了使学生能够获得较为全面的 实践机会, 我们选择了综合实力较强、 具有一定行业引领作用的晋江市社会 福利中心做为合作企业。该福利中心隶 属于晋江市民政局, 由晋江市民政局委 
托青鸟䝠居（晋江）养老服务有限公司 以公建民营的管理模式进行运营。该养 老机构是目前泉州市较为综合的养老 机构, 集休闲康养、医养结合于一体, 采用一平台、两中心、三基地运行模式, 一平台：智慧养老平台，两中心：医养 结合休闲康复中心、养老指挥调度中 心, 三基地: 养老管理服务人员培训基 地、养老学术研究基地、养老产业细分 协同基地。

试点班学员则以 17 级老年服务与管 理专业的学生为招募对象 (他们已完成 了第一阶段的学习任务), 由学生自主选 择是进入试点班学习还是留在学校学 习, 全年级共有 102 名学生, 最终确定了 33 名学生为试点班学员。

在大三上学期 (第二阶段), 即第5 学期, 试点班学生进入合作企业, 吃、 住、学习、生活均在企业, 由企业设置 专职管理人员对试点班的学生进行学 习和生活管理; 非试点班的学生则按原 培养方案继续留在学校完成与试点班 相同课程、相同学时的学习, 无跟岗实 习活动。

合作企业推选出工作经验丰富的专 业技术人员承担试点班的授课任务, 学 校方相应课程的教师负责对企业方授课 人员进行教学方面的指导。校企双方根 据企业特点共同讨论和制定学生在课余 时间的跟岗实习计划与内容, 包括全护 理区、半护理区、自理区、康复科、前 台、办公室、活动策划组、营销宣传组 等区域的工作计划和轮转计划, 直至课 程结束, 跟岗实习也随之结束。

大三下学期 (第三阶段), 即第6学 期, 所有课程结束, 学生进入顶岗实习 阶段。大三所有学生, 包括试点班的学 生均返回学校, 通过双向选择招聘会自 由选择顶岗实习单位。

\section{3 改革成效分析与研究}

3.1学生的专业认同感得以巩固, 就 业意识增强

在此方案实施前, 在与老年服务与 管理专业17级学生的多次交谈中我们发 现, 该专业学生的专业认同感低, 对前 途感觉十分迷茫, 不知道自己将来能做
什么。这使我们感觉到了压力, 我们希 望能尽最大努力帮助学生转变认识, 感 知面对老龄化社会所肩负的责任。通过 实施“课堂进企业”人才培养方案之后, 我们发现, 试点班学生的专业认同感明 显得到了巩固。在顶岗实习阶段, 17 级 老年服务与管理专业全年级102名学生 均通过学校的” 双选会” 选择了适合自 己的实习单位。当全体学生确定了实习 单位之后, 我们对实习单位人数进行统 计, 结果显示, 试点班的33名学员中, 有 30 人选择了专业对口的养老机构进行 顶岗实习，专业对口率达 $90.90 \%$ 。而非 试点班的 69 名学员中虽然也有 30 人选择 了专业对口的养老机构进行顶岗实习, 但专业对口率只有 $43.48 \%$ （见表1), 经 统计学处理 (卡方检验), 试点班与非试 点班学员的专业认同感具有显著差异 $(P<0.01$ ，见表2)。

表1 顶岗实习专业对口率比较表

\begin{tabular}{|c|c|c|c|}
\hline 实习生类别 & 实习生总数 & 对口实习人数 & 对口率 $(\%)$ \\
\hline 试点班 & 33 & 30 & 90.90 \\
\hline 非试点班 & 69 & 30 & 43.48 \\
\hline
\end{tabular}

表2 专业认同感差异性检验（卡方检 验）表

\begin{tabular}{|c|c|c|}
\hline 实习生类别 & 非对口实习人数 & 对口实习人数 \\
\hline 试点班 $(33)$ & 3 & 30 \\
\hline 非试点班 $(69)$ & 39 & 30 \\
\hline & \multicolumn{2}{|c|}{20.734} \\
\hline$p$ & \multicolumn{2}{|c|}{0.000} \\
\hline
\end{tabular}

受新冠病毒影响, 这一届毕业生的 就业率普遍降低, 我校亦是如此, 17 级 老年服务与管理专业 102 名学生中有 56 人就业, 参军 1 人, 参加专升本继续深造 14 人。全年级就业率 (含参军及专升本) 为 $69.61 \%$, 其中, 有 27 人选择了养老机 构, 专业对口率为 $38.03 \%$ 。试点班学员 就业情况: 就业 22 人, 专升本 2 人, 占试
点班就业人数的 $72.73 \%$, 其中 18 人选择 养老机构，专业对口率为75\%（见表3）。 从下表可以看出, 试点班学员的就业意 识强于非试点班学员且专业认同感亦明 显高于非试点学员。

\section{2一举多赢三方获利}

对于学校而言, 第一方面, 该方案 的实施加强了人才培养的实践教学环 节, 给学生提供更多的实训、实习机会 和途径, 让学生及时学习行业一线的新 知识、新技术，提升学生的工作实践和 创新能力, 从根本上解决高职院校人才 培养的针对性、适应性和有效性问题, 从而使人才培养的质量得到有效提升并 为学校优秀、合格人才的输出提供了良 好途径。第二方面, 通过人才培养模式 改革, 有效地帮助学生树立了职业价值 观, 提升了专业认同感, 学生的就业意 识和就业的专业对口率明显提高（见表 3)。第三方面, 收获了科研成果, 针对 该方案, 健康管理学院获得3项科研课题 立项，1项为全国职业教育科研规划课 题, 1 项为市级科研规划课题, 1 项为校 级课题, 目前均已结题。

对于合作企业而言, 第一方面, 学 生在企业边学习边跟岗实习, 在一定程 度上缓解了企业一线护理人员用工荒的 矛盾。虽然前期带徒需要耗费一定精力 和时间, 但学生们很快便掌握了一线护 理人员的工作流程和工作方法, 大量工 作由学生承担, 大大降低了一线护理人 员的工作强度, 节约了企业的用工成本。 而且, 学生还可以把所学的老年人照护 知识与一线护理人员探讨及分享, 优势 互补, 共同成长, 提升了养老机构的护 理质量。尤其是在疫情期间, 一线护理 人员明显不足的情况下, 这些留岗实习 的学生起到了非常重要的补充作用。第 二方面, 也是最重要的一个方面, 企业 拥有了优先录用优秀管理人才的权力, 贏得了优先储备优质人力资源的机会。

表 3 毕业生就业比较表

\begin{tabular}{|c|c|c|c|c|c|}
\hline $\begin{array}{c}\text { 毕业生 } \\
\text { 类别 }\end{array}$ & $\begin{array}{c}\text { 毕业生 } \\
\text { 总数 }(\text { 人) }\end{array}$ & $\begin{array}{c}\text { 就业人数 } \\
\text { (含参军专升本) }\end{array}$ & $\begin{array}{c}\text { 占毕业生人数 } \\
\text { 比例 }(\%)\end{array}$ & $\begin{array}{c}\text { 对口就业 } \\
\text { 人数 }(\text { 人) }\end{array}$ & $\begin{array}{c}\text { 占就业人数 } \\
\text { 比例 }(\%)\end{array}$ \\
\hline 全年级 & 102 人 & 71 人 & 69.61 & 27 & 38.03 \\
\hline 试点班 & 33人 & 24 人 & 72.73 & 18 & 75 \\
\hline
\end{tabular}


从学生所选择的实习单位可以看出, 在 43 家实习单位中, 有 28 家仅有 1 名我校的 实习生，而合作企业一家就拥有我校 24 名实习生, 占实习生总数的 $23.53 \%$, 是 获得我校该专业实习生最多的一个实习 单位（见表4)。从学生毕业后的就业情 况看, 试点班的 33 名学生中, 有 9 人选择 了在合作企业就业工作, 亦是获得我校 该专业应届毕业生最多的企业。

表4 各实习单位实习生人数分布比较表

\begin{tabular}{|c|c|c|c|}
\hline $\begin{array}{c}\text { 实习单位 } \\
\text { 数(家) }\end{array}$ & $\begin{array}{c}\text { 每单位 } \\
\text { 实习生 } \\
\text { 数(人) }\end{array}$ & $\begin{array}{c}\text { 累计实习 } \\
\text { 生数 (人) }\end{array}$ & $\begin{array}{c}\text { 占实习生 } \\
\text { 总数 }(\%)\end{array}$ \\
\hline 28 & 1 & 28 & 27.45 \\
\hline 5 & 2 & 10 & 9.80 \\
\hline 3 & 3 & 9 & 8.82 \\
\hline 3 & 4 & 12 & 11.76 \\
\hline 1 & 5 & 5 & 4.90 \\
\hline 1 & 6 & 6 & 5.88 \\
\hline 1 & 8 & 8 & 7.84 \\
\hline 1 & 24 & 24 & 23.53 \\
\hline $\begin{array}{c}\text { 合计 } \\
43\end{array}$ & $/$ & 102 & 100 \\
\hline
\end{tabular}

对于试点班的学生而言, 他们是最 大的受益者, 获得了校内同学无法获得 的工作经历和体验, 学到了许多在课堂 上、书本里学不到的东西, 甚至还学会 了如何进行入户篮查、如何进行公众平 台的日常运行与管理, 这些在学校统一 安排的跟岗实习中是学不到的。通过座 谈, 学生们谈的最多的是实践的真实体 验, 在学校, 基本上是在虚拟的环境中 以模拟的方式学习如何为老年人提供生 活照料和康复护理; 而在企业, 则是以 鲜活、真实的老年人为服务对象, 学习 如何对他们进行生活方面的照料与护理 服务, 如何协助他们接受康复治疗与训 练。学生们感受最深刻的就是给老年人
处理大小便, 从一开始的抗拒、不接受、 不适应, 到坦然面对、欣然接受、麻利 护理, 并且对健康、对青春有了不一样 的认识和理解, 这是一个完美的心理升 华过程, 专业认同感得以巩固, 职业价 值观得以树立。通过多样化的跟岗实习, 学生们的自身素质以及护理服务能力、 组织管理能力、活动策划能力等都得到 了明显提升, 学会了如何尊重人, 如何 与人进行交流与沟通, 从而比在校学习 的同学更有就业意识, 更能适应社会, 更快进入工作状态, 更易获得企业认可。

\section{4 方案的不足之处}

虽然, “课堂进企业” 人才培养模 式是一种互惠互利, 一举多赢的人才培 养模式。但依然有其不足之处, 其一、 将二、三十名或更多的学生放入一家企 业集中学习, 对于企业来说有一定难 度, 因此, 在安排学生实习时, 较难找 到有这种实力的企业, 从而使 “课堂进 企业” 人才培养模式的推广受到一定限 制。其二, 让企业技术人员承担授课任 务有一定难度且教学效果不理想。毕竟 理论教学有其自身的规律和特殊性, 虽 然企业技术人员有着姻熟的实际操作 技术, 但对按学校要求执行理论教学仍 有一定困难, 不是一朝一歹就能掌握的 技术。况且, 执行理论课授课任务需要 耗费大量时间和精力, 对于企业技术人 员来说不易做到, 致使教学效果不理 想。其三, 老年服务与管理专业学生的 就业范围十分宽泛, 涉及许多行业和企 业, 因此, 不能让全体学生只在单一的 养老机构进行跟岗实习, 使学生的管理 能力、组织能力和思维能力的发展受到 限制。

通过 “课堂进企业” 人才培养模式
的试运行, 我们积累了一定的改革经验, 认为这是一种值得推广的人才培养模 式, 而且有很大的发展与改革空间。然 而, 针对方案的不足之处, 我们还需要 做更深入的探讨与改革, 我们认为可以、 而且也有必要进一步拓展合作企业, 推 行多企业联合的方式, 把整个年级的学 生完全下放到多个不同类型的合作企业 中去, 使所有学生均能获得一次较为充 分的锻练并为后续的顶岗实习打下基 础。因此, 我们需要通过老年服务与管 理专业教学工作指导委员会与合作企业 共同商讨新的合作与改革方案, 使校企 合作、产教融合更进一步地向前发展。 我们相信, 通过新一轮人才培养方案的 改革与实施, 老年服务与管理专业的学 生将能够在进入顶岗实习前获得一次有 意义的锻炼, 从而为顶岗实习积累经验, 为步入社会积累经验, 使学生的人生阅 历更加丰富多彩。

\section{基金项目:}

泉州市社会科学规划项目立项课题 （编号2019H06）。

\section{[参考文献]}

[1]陈瑞英,刘炜.浙江省老年服务与 管理专业 “工学结合” 人才培养模式探 微[J]. 时代教育,2015,7(01):87-88.

[2]侯晓霞.基于校企协同育人的高 职人才培养模式创新与实践一以大连 职业技术学院老年服务与管理专业为例 [J]. 江苏经贸职业技术学院学 报,2017(01):80-83.

\section{作者简介：}

刘小玲 (1958--), 女, 汉族, 福 建泉州人, 副教授, 本科, 研究方向: 护理教育教、教育管理。 